Abstracta Iranica Abstracta Iranica

Revue bibliographique pour le domaine irano-aryen

Volume 32-33 | 2013

Comptes rendus des publications de 2009-2010

\title{
Javier Álvarez-Món. The Arjān Tomb at the Crossroad of the Elamite and the Persian Empires
}

\section{Astrid Nunn}

\section{(2) OpenEdition}

1 Journals

Édition électronique

URL : http://journals.openedition.org/abstractairanica/40134

DOI : 10.4000/abstractairanica.40134

ISSN : 1961-960X

\section{Éditeur :}

CNRS (UMR 7528 Mondes iraniens et indiens), Éditions de l'IFRI

\section{Édition imprimée}

Date de publication : 1 décembre 2013

ISSN : 0240-8910

\section{Référence électronique}

Astrid Nunn, « Javier Álvarez-Món. The Arjān Tomb at the Crossroad of the Elamite and the Persian Empires », Abstracta Iranica [En ligne], Volume 32-33 | 2013, document 23, mis en ligne le 01 juillet 2016, consulté le 29 septembre 2020. URL : http://journals.openedition.org/abstractairanica/40134 ; DOI : https://doi.org/10.4000/abstractairanica.40134

Ce document a été généré automatiquement le 29 septembre 2020.

Tous droits réservés 


\title{
Javier Álvarez-Món. The Arjān Tomb at the Crossroad of the Elamite and the Persian Empires
}

\author{
Astrid Nunn
}

\section{RÉFÉRENCE}

The Arjān Tomb at the Crossroad of the Elamite and the Persian Empires. Louvain, 2010, 352 p., 117 pl. en noir et blanc. (Acta Iranica 49)

1 Cette étude est une thèse de doctorat soutenue à l'Université de Californie à Berkeley. Les objets analysés sont conservés au National Museum of Iran à Téhéran. La chambre funéraire a été découverte lors de la construction d'une route de barrage en 1982 et est située à égale distance entre Suse et Persépolis. L'A. a déjà publié plusieurs articles sur les nombreux objets trouvés dans la tombe, où était enterré un homme âgé de 40 à 50 ans. La première partie de ce travail présente la tombe et le matériel, la seconde les replace dans un contexte historique, archéologique et stylistique plus large. Une troisième partie enfin est centrée sur la tombe et l'histoire élamite.

Que ce soit le sarcophage en bronze, les textiles en coton qui entouraient le défunt, ou les 98 bractéates (rosettes) en or trouvé sur sa poitrine, tout le matériel funéraire est présenté de manière extrêmement détaillée et comparé à des objets élamites et procheorientaux. Un des objets les plus extraordinaires est un anneau ouvert en or dont les ouvertures se terminent en palmettes. L'intérieur des palmettes est décoré de deux griffons érigés qui se font face. D'autres objets exceptionnels sont une épée, un candélabre très orné, un gobelet (voir Abs. Ir. 31, c.r. n³1) et une coupe décorée d'un diamètre de $43,5 \mathrm{~cm}$. Le lecteur pourra se rallier ou non à l'interprétation «biographique » des images de celle-ci par l'A. La tablette néo-élamite trouvée près de la tombe est un indice chronologique précieux qui s'ajoute aux analyses stylistiques. Ceci mène l'A. à adopter une date néo-élamite tardive entre 630 et $550 \mathrm{av}$. J.-C. pour 
cette tombe. Ce livre, d'autant plus facilement lisible que presque tous les objets cités dans le texte sont illustrés, est une mine sur l'art élamite des $\mathrm{VII}^{\mathrm{e}}-\mathrm{VI}^{\mathrm{e}} \mathrm{s}$.

\section{AUTEURS}

\section{ASTRID NUNN}

Université de Munich 